\title{
FAKTOR-FAKTOR YANG BERHUBUNGAN DENGAN PERILAKU KESELAMATAN DAN KESEHATAN KERJA (K3)
}

\author{
*Heni Fa’riatul Aeni**Nyimas Rahmiwaty Fermania
}

\begin{abstract}
ABSTRAK
Perilaku manusia yang berhubungan dengan keselamatan merupakan sebuah pendekatan untuk menganalisis apa yang dibutuhkan untuk membuat perilaku K3 lebih dimungkinkan dan mengurangi perilaku yang beresiko. PT Arteria Daya Mulia (ARIDA) Cirebon salah satu perusahaan yang memproduksi jaring dan tambang. Berdasarkan data kecelakaan kerja akibat tindakan yang tidak berperilaku K3 di PT Arteria Daya Mulia (ARIDA) Cirebon sebanyak 90\% di tahun 2014. Tujuan penelitian ini adalah untuk mengetahui faktor - faktor yang berhubungan dengan perilaku K3 di PT Arteria Daya Mulia (ARIDA) Cirebon Tahun 2015. Penelitian ini merupakan penelitian kuantitatif dengan desain cross sectional. Populasi pada penelitian ini berjumlah 2002 orang. Pengambilan data dilakukan secara propotional random sampling dengan jumlah sampel 92 responden. Analisis bivariat dilakukan dengan uji chi square pada tingkat kemaknaan 5\% (0.05). Hasil penelitian, diketahui $56.5 \%$ pekerja berperilaku K3 dan $43.5 \%$ pekerja yang tidak berperilaku K3. Faktor - faktor yang tidak berhubungan dengan perilaku K3 adalah pelatihan, penghargaan dan hukuman. Sedangkan faktor - faktor yang berhubungan dengan perilaku K3 adalah pengetahuan, sikap, motivasi, komunikasi,ketersediaan fasilitas dan pengawasan.
\end{abstract}

Kata kunci : Faktor Predisposing, enabling, reinforcing,Perilaku K3

\section{ABSTRACT}

Human behavior associated with safety is an approach to analyze what is needed to make the behavior more likely K3 and diminish risk behaviors. PT Arteria Daya Mulia Cirebon (ARIDA) one of the companies that manufacture net and mine. Based on data from workplace accidents due to actions that do not behave K3 PT Arteria Daya Mulia (ARIDA) Cirebon as much as $90 \%$ in 2014. The aim of this research is to know factors factors related to the behavior of K3 PT Arteria Daya Mulia (ARIDA) Cirebon 2015. This research is a quantitative with cross sectional design. The population in this study amounted to 2002 people. Data collection was performed by proportional random sampling with a sample of 92 respondents. Bivariate analysis performed by the chi square test at $5 \%$ significance level $(0.05)$. Results of the study, $56.5 \%$ of workers are known to behave K3 and $43.5 \%$ of workers who do not behave K3. Factors - factors that are not related to the behavior of $\mathrm{K} 3$ is training, reward and punishment. While factors - factors related to the behavior of K3 are the knowledge, attitudes, motivation, communication, availability of facilities and supervision.

Kata kunci : Predisposing, enabling, reinforcing, K3 behavior

\footnotetext{
* Staf Pengajar PSKM STIKes Cirebon

** Alumni PSKM STIKes Cirebon Lulus Tahun 2015
} 


\section{PENDAHULUAN}

Terjadinya kecelakaan kerja tentu saja menjadikan masalah yang besar bagi kelangsungan suatu usaha. Kerugian yang diderita tidak hanya berupa kerugian materi yang cukup besar namun lebih dari itu adalah timbulnya korban jiwa yang tidak sedikit jumlahnya. Kehilangan sumber daya manusia ini merupakan kerugian yang sangat besar karena manusia adalah satu-satunya sumber daya yang tidak dapat digantikan oleh teknologi apapun. ${ }^{1}$

Pemerintah telah memberlakukan undang - undang keselamatan kerja yaitu undang undang nomor 1 tahun 1970, dan untuk mengatur prinsip - prinsip kesehatan karyawan di tempat kerja telah termuat dalam undang - undang nomor 23 tahun 1992. Jelas dikatakan pada undang - undang nomor 1 tahun 1970 bahwa keselamatan kerja merupakan suatu upaya pemberian perlindungan kepada tenaga kerja dan orang lain dari potensi yang dapat menimbulkan bahaya yang berasal dari mesin - mesin, alat kerja, bahan dan energi. Tidak ditinggalkan perlindungan dari bahaya lingkungan kerja, sifat pekerjaan, cara kerja dan proses produksi. Kemudian undang - undang nomor 23 tahun 1992 menyebutkan bahwa kesehatan kerja diselenggarakan untuk mewujudkan produktivitas kerja yang optimal. Kesehatan kerja meliputi pelayanan kesehatan kerja, pencegahan penyakit akibat kerja dan syarat kesehatan kerja. $^{2}$

Melaksanakan program K3 di tempat kerja diantaranya mempunyai tujuan untuk menjaga agar pekerja tetap sehat dan selamat selama bekerja. Derajat kesehatan menurut Henrik L Bloom dapat dipengaruhi oleh empat faktor yaitu lingkungan, genetik, layanan kesehatan dan perilaku. ${ }^{3}$ Perilaku tidak selamat dan tidak sehat dalam bekerja dapat dicegah dengan mulai memperbaiki manajemen K3. Perilaku di bawah standar atau unsafe act dan kondisi di bawah standar atau unsafe conditions merupakan penyebab langsung suatu kecelakaan dan penyebab utama dari kesalahan manajemen. Dalam pekerjaan pasti ada resiko terjadinya kecelakaan kerja, penyakit akibat kerja dan kebakaran. Hal ini disebabkan oleh pekerja tidak berperilaku K3, pekerjaan yang tidak aman, sarana dan prasarana yang tidak memenuhi syarat dan tidak dikelola dengan baik atau disebabkan oleh lingkungan yang tidak aman. Hal yang lebih buruk lagi adalah sistem pengelolaan atau manajemen yang buruk. Kerugian sebagai dampak dari kecelakaan kerja dapat berupa cidera pada karyawan, sarana dan prasarana penunjang, bahkan lingkungan secara keseluruhan. ${ }^{2}$

Human error dalam pekerjaan yang mempunyai resiko tinggi merupakan kejadian yang dilandasi oleh perilaku K3 individu yang buruk meskipun perilaku K3 adalah bentuk respon atau reaksi terhadap stimulus atau rangsangan dari luar organisme (orang), namun dalam memberikan respon sangat tergantung pada karakteristik atau faktor - faktor lain dari orang yang bersangkutan. Hal ini berarti meskipun stimulusnya sama bagi beberapa orang, namun respon tiap - tiap orang berbeda. Faktor - faktor yang membedakan respons terhadap stimulus yang berbeda disebut determinan perilaku. Determinan perilaku ini dapat dibedakan menjadi dua, yakni determinan internal seperti tingkat kecerdasan dari pendidikan yang didapat, jenis kelamin, pengetahuan, aktivitas fisik, persepsi dan sikap. Determinan berikutnya adalah determinan eksternal seperti lingkungan sosial, budaya, ekonomi, tempat kerja dan lainnya. ${ }^{3}$

Menurut Badan Penyelenggara Jaminan Sosial (BPJS) Ketenagakerjaan mendata selama 2013 jumlah peserta yang mengalami kecelakaan kerja sebanyak 129.911 orang yaitu 146.219 orang berjenis kelamin laki-laki dan 46.692 berjenis kelamin perempuan, dimana $69,59 \%$ kecelakaan terjadi di dalam perusahaan saat bekerja, 10,26\% kecelakaan terjadi di luar perusahaan, dan sekitar 20,15\% pekerja mengalami kecelakaan lalu lintas. Sementara akibat kecelakaan tersebut, jumlah peserta BPJS Ketenagakerjaan yang meninggal sebanyak 3.093 pekerja, yang mengalami sakit 15.106 pekerja, luka-luka 174.266 pekerja, dan meninggal mendadak sebanyak 446 pekerja. Sebanyak 34,43\% penyebab kecelakaan kerja 
dikarenakan posisi tidak aman atau ergonomis dan sebanyak 32,12\% pekerja tidak memakai peralatan yang safety. ${ }^{4}$

Berdasarkan data BPJS Ketenagakerjaan, jumlah kecelakaan kerja di Provinsi Jawa Barat sepanjang tahun 2013 berjumlah 22.438 kasus dengan besaran klaim mencapai Rp 89,75 miliar rupiah. ${ }^{4}$ Makhrudin (2007) dalam buku yang di kutip tentang perilaku pekerja terhadap pelaksanaan program K3 menyebutkan bahwa masih banyak pekerja yang belum memahami betul mengenai istilah K3. Tetapi dalam penelitiannya tentang perilaku K3, Makhrudin (2007) menunjukan bahwa sebanyak $78,18 \%$ saja pekerja yang mempunyai perilaku tidak baik mengenai K3. ${ }^{5}$

PT Arteria Daya Mulia (ARIDA) berada dalam lokasi peruntukan termasuk Bagian Wilayah Kota (BWK) III yaitu Pusat pengembangan industri sesuai dengan Rencana Tata Ruang Kota (RTRW) Kota Cirebon. Alamat lokasi Usaha atau kegiatan jalan Dukuh Duwur No 46 kelurahan Pegambiran Kecamatan Lemah Wungkuk Kota Cirebon. PT Arteria Daya Mulia (ARIDA) bergerak dibidang usaha Industri tali temali (bijih plastik, benang nylon, tambang plastik dan jala ikan) termasuk industri tekstil. Daerah pemasaran hasil produksi PT Arteria Daya Mulia (ARIDA) meliputi pasar dalam negeri dan eksport ke negara-negara lain seperti Vietnam, Singapura, Jepang, Timur-Tengah, Amerika Tengah dan Eropa. Teknologi yang digunakan PT. Arteria Daya Mulia (ARIDA) adalah teknologi modern dan menggunakan mesin-mesin yang potensial untuk menghasilkan kapasitas produksi yang cukup tinggi. ${ }^{6}$

Data Kecelakaan kerja yang terjadi sampai tahun 2014 di PT Arteria Daya Mulia (ARIDA) sebanayak 30 kasus yang 90\% kecelakaan kerja terjadi karena perilaku K3 yang kurang baik. Contoh kasus yaitu pekerja sedang memperbaiki benang rusak pada roll mesin tapi mesin tidak dimatikan sehingga tangan kanan masuk ke roll mesin tersebut. Walaupun kecelakaan kerja mengalami pernurun dari tahun sebelumnya akan tetapi setiap perusahaan pasti menginginkan angka zero accident. Untuk itu perilaku K3 di PT Arteria Daya Mulia (ARIDA) masih belum dikatakan baik. ${ }^{7}$

Komitmen bersama dapat dibangun apabila terjadi pemahaman yang relatif sama tentang K3 pada seluruh karyawan. Pengetahuan K3 sesuai teori dan konsep akan membawa karyawan pada pemahaman dan persepsi yang benar juga utuh sehingga dalam diri karyawan akan terbentuk sikap dan perilaku yang positif terhadap K3 di PT Arteria Daya Mulia (ARIDA) Cirebon. ${ }^{9}$ Penelitian ini bertujuan untuk mengetahui faktor-faktor yang berhubungan dengan perilaku K3 di PT Arteria Daya Mulia (ARIDA).

\section{METODE PENELITIAN}

Penelitian ini dilakukan menggunakan pendekatan kuantitatif dengan desain cross sectional. ${ }^{10}$ Variabel bebas dalam penelitian ini adalah pengetahuan, pelatihan, sikap, motivasi dan komunikasi ketersediaan fasilitas, pengawasan, hukuman dan penghargaan. Variabel terikat dalam penelitian ini adalah perilaku K3. Populasi dalam penelitian ini adalah seluruh pekerja di PT Arteria Daya Mulia (ARIDA) Cirebon tahun 2015 yang berjumlah 2002 orang. Teknik pengambilan sampel secara proportionate random sampling (pengambilan sample secara proposional). ${ }^{9}$

Maka besar sampel dalam penelitian berdasarkan hasil perhitungan di atas diperoleh sampel 92 responden, yang terdiri dari bagian personalia 3 responden, supir 1, satpam 1, akuntan 1, jaring A 11, jaring B 9, BPP 8, bagian benang 7, bagian tambang exp. PE 5, Fns. Mono Yoko 9, Fns. Mono Tate 6, Fns. Multy 10, QC PG I 3, Utility 4, Extruder mono 3, Polimer 1, dan bagian spinning 5 responden.

Analisis yang digunakan untuk mengetahui hubungan antara variabel bebas (pengetahuan, pelatihan, sikap, motivasi, ketersediaan fasilitas penunjang, pengawasan, 
hukuman dan penghargaan), dan variabel terikat (perilaku K3) dilakukan dengan uji statistik uji chi square.

\section{HASIL PENELITIAN \\ Perilaku K3}

Hasil penelitian menunjukan bahwa perilaku K3 pada pekerja diperoleh responden berada pada kategori baik yaitu 52 orang (56.5\%) dan kategori tidak baik 40 orang $(43.5 \%)$

\section{Faktor Predisposing}

Faktor predisposing dalam penelitian ini meliputi 5 sub variabel terdiri dari pengetahuan, pelatihan, sikap, motivasi, dan komunikasi menunjukkan bahwa faktor predisposing dengan presentase paling tinggi pada sub variabel motivasi dengan kategori baik sebesar 68 (73.9\%) pekerja.

\section{Faktor Enabling}

Faktor enabling dalam penelitian ini meliputi 1 variabel yaitu ketersediaan fasilitas. Hasil penelitian menunjukan bahwa ketersediaan fasilitas pada pekerja diperoleh dengan kategori lengkap yaitu $48(52.2 \%)$ pekerja.

\section{Faktor Reinforcing}

Faktor reinforcing dalam penelitian ini meliputi 3 sub variabel yaitu pengawasan, hukuman, dan penghargaan. Hasil penelitian menunjukan bahwa faktor reinforcing dengan persentase paling tinggi yaitu pada sub variabel pengawasan dengan kategori ada sebanyak 86 $(93.5 \%)$ pekerja.

\section{Hubungan Faktor predisposing dengan Perilaku K3}

Tabel 1. Hubungan Faktor Predisposing dengan Perilaku K3

\begin{tabular}{|c|c|c|c|c|c|c|c|}
\hline \multirow{3}{*}{ Faktor Predisposing } & \multicolumn{4}{|c|}{ Perilaku K3 } & & & \multirow{3}{*}{$P$ Value } \\
\hline & \multicolumn{2}{|c|}{ Kurang Baik } & \multicolumn{2}{|c|}{ Baik } & \multicolumn{2}{|c|}{ Jumlah } & \\
\hline & $\mathrm{n}$ & $\%$ & $\mathrm{n}$ & $\%$ & $\mathrm{n}$ & $\%$ & \\
\hline Pengetahuan & & & & & & & 0.000 \\
\hline Kurang baik & 22 & 71.0 & 9 & 29.0 & 31 & 100 & \\
\hline Baik & 18 & 29.9 & 43 & 70.0 & 61 & 100 & \\
\hline Pelatihan & & & & & & & 0.197 \\
\hline Tidak pernah & 24 & 51.1 & 23 & 48.9 & 47 & 100 & \\
\hline Pernah & 16 & 35.6 & 29 & 64.4 & 45 & 100 & \\
\hline Sikap & & & & & & & 0.058 \\
\hline Kurang baik & 25 & 54.3 & 21 & 45.7 & 46 & 100 & \\
\hline Baik & 15 & 32.6 & 31 & 67.4 & 46 & 100 & \\
\hline Motivasi & & & & & & & 0.001 \\
\hline Kurang baik & 18 & 75.0 & 6 & 25.0 & 24 & 100 & \\
\hline Baik & 22 & 32.4 & 46 & 67.6 & 68 & 100 & \\
\hline Komunikasi & & & & & & & 0.000 \\
\hline Kurang baik & 30 & 69.8 & 13 & 30.2 & 43 & 100 & \\
\hline Baik & 10 & 20.4 & 39 & 79.6 & 49 & 100 & \\
\hline
\end{tabular}

Dalam tabel 1. menunjukan bahwa Hasil uji chi-square menunjukan adanya hubungan antara pengetahuan nilai Pvalue $=0,000$, motivasi $($ Pvalue $=0.001)$, dan komunikasi $(\mathrm{P} v a l u e=0.000)$ dengan perilaku K3 di PT Arteria Daya Mulia (ARIDA) Cirebon Tahun 2015. 


\section{Hubungan Faktor Enabling dengan Perilaku K3}

Tabel 2. Hubungan Faktor Enabling dengan Perilaku K3

\begin{tabular}{|c|c|c|c|c|c|c|c|}
\hline \multirow{3}{*}{ Ketersediaan Fasilitas } & \multicolumn{4}{|c|}{ Perilaku K3 } & & & \multirow{3}{*}{$P$ Value } \\
\hline & \multicolumn{2}{|c|}{ Kurang Baik } & \multicolumn{2}{|c|}{ Baik } & \multicolumn{2}{|c|}{ Jumlah } & \\
\hline & $\mathrm{n}$ & $\%$ & $\mathrm{n}$ & $\%$ & $\mathrm{n}$ & $\%$ & \\
\hline Kurang lengkap & 34 & 77.3 & 10 & 22.7 & 44 & 100 & \\
\hline Lengkap & 6 & 12.5 & 42 & 87.5 & 48 & 100 & 0,000 \\
\hline Jumlah & 40 & 43.5 & 52 & 56.5 & 92 & 100 & \\
\hline
\end{tabular}

Pada tabel 2 hasil penelitian menunjukan ada hubungan antara ketersediaan fasilitas dengan perilaku K3 di PT Arteria Daya Mulia (ARIDA) Cirebon Tahun 2015 dengan nilai Pvalue $=0,000$.

\section{Hubungan Faktor Reinforcing dengan Perilaku K3}

Tabel 3. Hubungan Faktor Reinforcing dengan Perilaku K3

\begin{tabular}{|c|c|c|c|c|c|c|c|}
\hline \multirow[t]{3}{*}{ Faktor Reinforcing } & \multicolumn{4}{|c|}{ Perilaku K3 } & & & \multirow{3}{*}{$P$ Value } \\
\hline & \multicolumn{2}{|c|}{ Kurang Baik } & \multicolumn{2}{|c|}{ Baik } & \multicolumn{2}{|c|}{ Jumlah } & \\
\hline & $\mathrm{n}$ & $\%$ & $\mathrm{n}$ & $\%$ & $\mathrm{n}$ & $\%$ & \\
\hline \multicolumn{8}{|l|}{ Pengawasan } \\
\hline Tidak ada & 5 & 83.3 & 1 & 16.7 & 6 & 100 & 0.082 \\
\hline Ada & 35 & 40.7 & 51 & 59.3 & 86 & 100 & \\
\hline Hukuman & & & & & & & 0.239 \\
\hline Tidak ada & 28 & 49.1 & 29 & 50.9 & 57 & 100 & \\
\hline Ada & 12 & 34.3 & 23 & 65.7 & 35 & 100 & \\
\hline Penghargaan & & & & & & & 0.406 \\
\hline Tidak ada & 37 & 45.7 & 44 & 54.3 & 81 & 100 & \\
\hline Ada & 3 & 27.3 & 8 & 72.7 & 11 & 100 & \\
\hline
\end{tabular}

Pada tabel 3. Hasil penelitian menunjukan bahwa tidak ada hubungan antara factor reinforcing dengan perilaku K3 di PT Arteria Daya Mulia (ARIDA) Cirebon Tahun 2015 dengan Pvalue $>0.05$.

\section{PEMBAHASAN}

\section{Perilaku K3}

Perilaku K3 yaitu tindakan yang berhubungan dengan K3 di tempat kerja, untuk meminimalisir kecelakaan kerja. Sahab (1997) mengatakan bahwa kegagalan dalam menjalankan misi K3 karena kurangnya motivasi untuk bekerja dengan selamat. Ia juga mengatakan bahwa komunikasi K3 diperlukan untuk mendorong perubahan perilaku sehingga termotivasi untuk bekerja dengan selamat. ${ }^{10}$

\section{Faktor Predisposing}

\section{Pengetahuan}

Penelitian yang telah dilakukan pada pekerja di PT Arteria Daya Mulia (ARIDA) Cirebon tahun 2015 didapatkan para pekerja yang pengetahuannya baik sebanyak 61 (66.3\%). Menurut Notoatmodjo (2005), pengetahuan merupakan hasil dari tahu, terjadi setelah orang melakukan proses penginderaan terhadap objek yang diamatinya. ${ }^{3}$ Hal ini menunjukan bahwa semakin tinggi pengetahuan pekerja maka akan semakin tinggi 
perilaku selamat yang dilakukan pekerja dan semakin rendah pengetahuan seseorang maka semakin kecil kemungkinan untuk berperilaku K3.

Kenyataan ini sejalan dengan pendapat oleh Adenan (1999) bahwa semakin luas pengetahuan seseorang maka semakin positif perilaku yang dilakukannya. Perilaku positif mempengaruhi jumlah informasi yang dimiliki seseorang sebagai hasil proses penginderaan terhadap objek tertentu. ${ }^{11}$

Hasil penelitian diatas sesuai dengan pendapat Green yang menyatakan bahwa pengetahuan merupakan salah satu faktor berpengaruh (predisposing factor) yang mendorong atau menghambat individu untuk berperilaku. ${ }^{12}$ Pada dasarnya pekerja mengetahui dengan baik bahaya yang ada di tempat kerja tetapi mereka tetap tidak berperilaku $\mathrm{K} 3$ dan cenderung mengabaikan keselamatan karena mereka merasa sudah terbiasa untuk tidak berperilaku K3 seperti tidak memakai APD dengan lengkap dan benar, menaruh sarung tangan sembarangan. Hal ini dikarenakan pekerja merasa mengenal dengan baik area kerjanya sehingga mengabaikan keselamatannya dengan tidak berperilaku K3 dan belum menyadari pentingnya berperilaku K3.

\section{Pelatihan}

Pekerja yang tidak pernah mengikuti pelatihan yaitu sebanyak 47 (51.1\%). Hal ini disebabkan karena pelatihan keselamatan dilakukan bersifat sukarela dan wajib. Pelatihan yang bersifat sukarela biasanya diwakilkan beberapa orang dalam satu section produksi. Meskipun demikian, tidak menutup kemungkinan semua pekerja bisa mengikuti pelatihan karena pelatihan ini dilakukan secara bergiliran.

Hasil penelitian menunjukan bahwa p value $=0.197(\alpha>0.05)$ yang berarti tidak ada hubungan antara pelatihan dengan perilaku K3. Syaaf (2008) juga mengemukakan bahwa pelatihan merupakan faktor perilaku yang sangat penting untuk terbentuknya perilaku seseorang, bila pekerja pernah mengikuti sehingga dapat menilai potensi bahaya dalam perilaku K3. ${ }^{12}$

Hal ini menunjukan sering atau jarangnya pelatihan dilakukan tidak mempengaruhi perilaku K3 pekerja karena perubahan dan pembentukan perilaku tidak terjadi begitu saja tetapi dipengaruhi oleh beberapa variabel lainnya seperti yang telah dipaparkan oleh Notoadmojo, bahwa perilaku sebagai perekfleksian faktor - faktor kejiwaan seperti keinginan, minat, kehendak, pengetahuan, emosi, sikap, motivasi, reaksi dan sebagainya, dan faktor lain seperti pengalaman, keyakinan, sarana fisik, sosio dan budaya. ${ }^{13}$

\section{Sikap}

Berdasarkan penelitian yang telah dilakukan pada pekerja di PT Arteria Daya Mulia (ARIDA) Cirebon tahun 2015 menunjukan hampir tidak ada perbedaan sikap pekerja disebabkan karena tidak adanya perbedaan pekerjaan yang berarti dan lingkungan kerja yang relatif sama sehingga sumber bahaya dan tingkat resiko akan terjadinya kecelakaan dan sakit akibat kerja. Selain itu, sistem nilai dari suatu individu maupun kelompok yang berkembang mempengaruhi pembentukan pemahaman tentang K3. Sudah berfungsinya manajemen $\mathrm{K} 3$ di perusahaan tersebut turut mempengaruhi pembentukan sikap pekerja yang beragam. Fakta ini sesuai dengan pendapat Notoatmodjo (2007) yang mengatakan bahwa sikap adalah reaksi atau respon yang masih tertutup dari seseorang terhadap suatu stimulus atau objek. ${ }^{3}$

Hasil penelitian menunjukan bahwa tidak ada hubungan antara sikap dengan perilaku K3 pada pekerja di PT Arteria Daya Mulia (ARIDA) Cirebon tahun 2015. Hasil penelitian di atas tidak sesuai dengan pendapat Green menyatakan sikap merupakan salah satu faktor yang berpengaruh (predisposing factor) yang mendorong atau menghambat individu untuk 
berperilaku. ${ }^{12}$ Menurut Morgan (1961) bahwa sikap adalah kecenderungan untuk berespon baik secara positif atau negatif terhadap orang, objek atau situasi. ${ }^{11}$ Sementara menurut Suma'mur (1996) mengatakan bahwa sikap dan pemahaman tentang K3 pada akhirnya ditampilkan dalam bentuk sikap dan perilaku seseorang atau sekelompok masyarakat mengenai $\mathrm{K} 3$. $^{2}$

Pendapat diatas sesuai dengan fakta yang didapat dalam penelitian, dengan maksimalnya kegiatan K3 yang dilakukan secara koordinasi dan teratur mengakibatkan adanya sikap positif dari pekerja. Baiknya sosialisasi tentang sumber bahaya dan manfaat K3 di lingkungan kerja pekerja menumbuhkan sikap yang sangat peduli di kalangan pekerja.

\section{Motivasi}

Penelitian yang telah dilakukan pada pekerja di PT Arteria Daya Mulia (ARIDA) Cirebon tahun 2015 menunjukan bahwa pekerja yang memiliki motivasi lebih baik sebesar 68 (73.9\%). Menurut Munandar (2001) motivasi adalah suatu proses dimana kebutuhan kebutuhan mendorong seseorang untuk melakukan serangkaian kegiatan yang mengarah kepada tercapainya tujuan tertentu. ${ }^{14}$ Sialagan (2008) juga mengatakan faktor - faktor yang mendorong motivasi pekerja adalah pemenuhan rasa puas pekerja yang dialami (faktor intrinsik), misalnya seperti keberhasilan mencapai sesuatu, diperolehnya pengakuan, rasa tanggung jawab, kemajuan karir, rasa profesionalisme dan intelektual. Dorongan yang ada dalam diri pekerja untuk berperilaku K3 juga harus didukung perusahaan dengan penciptaan lingkungan yang memfasilitasi terjadinya perilaku K3 di tempat kerja. ${ }^{15}$

Hasil penelitian menunjukan p value $=0.001(\alpha<0.05)$ yang berarti ada hubungan antara motivasi dengan perilaku K3 di PT Arteria Daya Mulia (ARIDA) Cirebon tahun 2105.

Pendapat Green yang menyatakan motivasi merupakan salah satu faktor berpengaruh (predisposing factor) yang mendorong atau menghambat individu untuk berperilaku. ${ }^{13}$ Berbeda dengan penelitian yang dilakukan Halimah (2009) bahwa pekerja yang memiliki motivasi rendah lebih banyak karena semakin rendah motivasi pekerja maka semakin tinggi tidak berperilaku K3. Hal ini menunjukan bahwa motivasi pekerja berbeda sehingga para pekerja mempunyai alasan masing - masing dalam berperilaku K3. Adapun motivasi pekerja dapat mempengaruhi seseorang dalam bekerja karena bekerja di PT Atreria Daya Mulia (ARIDA) Cirebon. Motivasi pekerja di PT Arteria Daya Mulia (ARIDA) Cirebon pada dasarnya memiliki motivasi yang sama yaitu bekerja dengan aman agar selamat dan bebas dari kecelakaan serta penyakit akibat kerja.

\section{Komunikasi}

Penelitian yang telah dilakukan pada pekerja di PT Arteria Daya Mulia (ARIDA) Cirebon tahun 2015 menunjukan bahwa pekerja yang memiliki komunikasi baik sebesar 49 (53.3\%). Pendapat Bandura dalam Syaaf (2008) yang mengemukakan bahwa komunikasi merupakan faktor perilaku yang sangat penting untuk terbentuknya perilaku seseorang, bila pekerja memiliki komunikasi yang baik. ${ }^{12}$

Hasil penelitian menunjukan bahwa Pvalue $0.000(\alpha<0.05)$ yang berarti ada hubungan antara komunikasi dengan perilaku K3 pada pekerja di PT Arteria Daya Mulia (ARIDA) Cirebon tahun 2015. Sahab (1997) mengatakan bahwa kegagalan dalam menjalankan misi K3 karena kurangnya motivasi untuk bekerja dengan selamat. Ia juga mengatakan bahwa komunikasi K3 diperlukan untuk mendorong perubahan perilaku sehingga termotivasi untuk bekerja dengan selamat. ${ }^{10}$ 
Hal ini mungkin dikarenakan bentuk komunikasi yang dilakukan mengenai pelaporan dan identifikasi resiko dan bahaya yang tidak mengganggu pekerjaan sehingga tidak mengurangi kinerja dalam melakukan tugas mereka sesuai standar operasional prosedur.

\section{Faktor Enabling \\ Ketersediaan fasilitas}

Penelitian yang telah dilakukan pada pekerja di PT Arteria Daya Mulia (ARIDA) Cirebon tahun 2015 menunjukan bahwa pekerja yang menjawab APD lengkap sebanyak 48 (52.2\%). Hasil penelitian menunjukan bahwa $\mathrm{p}$ value $=0.000(\alpha<0.05)$ yang berarti ada hubungan antara ketersediaan Fasilitas APD di PT Arteria Daya Mulia (ARIDA) Cirebon tahun 2015.

Hasil penelitian di atas sesuai dengan pendapat Green yang menyatakan ketersedian APD merupakan salah satu faktor pemungkin (enabling factor) yang mendorong atau menghambat individu untuk berperilaku. ${ }^{13}$ Ketersediaan APD merupakan salah satu faktor yang mendorong atau menghambat individu untuk berperilaku. Ketersediaan APD juga merupakan faktor lingkungan yang sangat penting untuk terbentuknya perilaku seseorang. Bila pekerja menggunakan APD yang ada maka dapat mencegah resiko dan bahaya yang ada di tempat kerja. ${ }^{12}$

\section{Faktor Reinforcing \\ 1. Pengawasan}

Berdasarkan penelitian yang telah dilakukan pada pekerja di PT Arteria Daya Mulia (ARIDA) Cirebon tahun 2015 menunjukan bahwa pekerja yang mengatakan terdapat pengawasan lebih banyak sebesar $86(93.5 \%)$ daripada pekerja yang mengatakan tidak ada pengawasan yaitu sebesar $6(6.5 \%)$.

Hasil penelitian menunjukan bahwa p value $=0.082(\alpha>0.05)$ yang berarti tidak ada hubungan antara pengawasan dengan perilaku K3 pada pekerja di PT Arteria Daya Mulia (ARIDA) Cirebon tahun 2015. Berbeda dengan hasil penelitian yang dilakukan oleh Arianto Wibowo (2010) didapatkan Pvalue 0.000 (Pvalue < 0.05) sehingga menunjukan ada hubungan bermakna antara pengawasan dengan perilaku K3. Kemungkinan bias dalam variabel ini karena pengawasan yang dilakukan tidak hanya bersifat khusus yaitu perilaku K3 tetapi juga pengawasan yang bersifat umum yaitu pengawasan terhadap kinerja para pekerja di PT Arteria Daya Mulia (ARIDA) Cirebon. ${ }^{16}$

Peran seorang pengawas sangat penting dan harus dapat memanfaatkan waktu dengan baik dalam berbicara untuk memberitahukan ataupun memberikan teguran terhadap pekerja yang tidak melakukan perilaku K3 dan memberikan pujian pada pekerja yang mengikuti prosedur kerja di tempat kerja. Kontak secara personal harus dilakukan sesering mungkin untuk mempengaruhi sikap pekerja, pengetahuan dan keterampilan. ${ }^{13}$

Pengamatan di lapangan, masih ada pengawas yang kurang tegas mengawasi pekerja yang tidak berperilaku K3, masih ada pekerja yang walaupun sudah ditegur tetapi masih tidak berperilaku K3 dan berperilaku K3 jika diawasi saja. Oleh karena itu perlu dilakukan pengawasan secara teratur atau konsisten sehingga apabila kondisi yang berbahaya atau kegiatan yang tidak berperilaku K3 dapat diketahui dengan segera dan dapat dilakukan usaha untuk memperbaikinya. Diharapkan bahwa pengawasan terhadap aktivitas pekerja ini dapat menumbuhkan kepatuhan dan kesadaran akan pentingnya keselamatan dan kesehatan kerja bagi dirinya, pekerja lain dan lingkungannya.

\section{Hukuman}

Berdasarkan penelitian yang telah dilakukan pada pekerja di PT Arteria Daya Mulia (ARIDA) Cirebon tahun 2015 menunjukan bahwa pekerja yang mengatakan hukuman 
tidak ada lebih banyak yaitu sebesar $57(62.0 \%)$ daripada pekerja yang mengatakan ada hukuman lebih sedikit yaitu sebesar 35 (38.0\%).

Hasil penelitian menunjukan bahwa Pvalue $=0.239(\alpha>0.05)$ yang berarti tidak ada hubungan antara hukuman dengan perilaku K3 pada pekerja di PT Arteria Daya Mulia (ARIDA) Cirebon tahun 2015. Berbeda dengan penelitian yang dilakukan Asriyani (2011) didapatkan Pvalue 0.000 (Pvalue < 0.05) sehingga menunjukan ada hubungan bermakna antara hukuman dengan perilaku K3. Kemungkinan bias pada variabel ini karena hukuman yang diberikan kepada pekerja hanya bersifat ringan yaitu berupa teguran saja. ${ }^{16}$

Hal ini dikemukakan melalui Model ABC, hukuman sebagai konsekuensi dari peristiwa lingkungan yang memberikan hasil negatif akibat suatu pekerjaan yang dilakukan. Peraturan yang diterapkan kepada pekerja bersifat lisan, sehingga kemungkinan pekerja melakukan pelanggaran. Kalau terjadi pelanggaran, hukuman yang diberikan tidak signifikan atau berarti karena hukuman hanya berupa teguran saja. ${ }^{12}$

\section{Penghargaan}

Berdasarkan penelitian yang telah dilakukan pada pekerja di PT Arteria Daya Mulia (ARIDA) Cirebon tahun 2015 menunjukan bahwa pekerja yang mengatakan terdapat penghargaan lebih sedikit yaitu sebesar $11(12.0 \%)$ daripada yang mengatakan tidak ada penghargaan yaitu sebesar $81(88.0 \%)$.

Hasil penelitian menunjukan bahwa Pvalue $=0.406(\alpha>0.05)$ yang berarti tidak terdapat hubungan antara penghargaan dengan perilaku K3 pada pekerja di PT Arteria Daya Mulia (ARIDA) Cirebon tahun 2015. Berbeda dengan penelitian yang dilakukan oleh Syaaf (2008) didapatkan Pvalue 0.000 (Pvalue < 0.05) sehingga menunjukan ada hubungan bermakna antara penghargaan dan perilaku K3. Kemungkinan bias pada variabel ini karena penghargaan yang diberikan hanya bersifat stimulan untuk bekerja lebih giat lagi berupa pujian dan bertambahnya pendapatan dari pemilik usaha. ${ }^{12}$

Peraturan yang ditetapkan oleh pemilik usaha kepada para pekerja bersifat lisan, sehingga terdapat kemungkinan pekerja melakukan pekerjaan dengan tidak baik. Kalau pekerja melakukan pekerjaan dengan baik, reward yang diberikan tidak signifikan atau berarti karena penghargaan hanya berupa penambahan pendapatan saja.

\section{SIMPULAN}

1. Perilaku K3 di PT Arteria Daya Mulia (ARIDA) Cirebon tahun 2015 bahwa pekerja yang berperilaku K3 adalah sebanyak 52 orang. Sedangkan pekerja yang tidak berperilaku K3 sebanyak 40 orang.

2. Hubungan antara faktor predisposing (pengetahuan, pelatihan, sikap, motivasi dan komunikasi) dengan perilaku pekerja dalam perilaku K3.

1) Ada hubungan antara pengetahuan dengan perilaku K3 di PT Arteria Daya Mulia (ARIDA) Cirebon tahun 2015.

2) Tidak ada hubungan antara pelatihan dengan perilaku K3 di PT Arteria Daya Mulia (ARIDA) Cirebon tahun 2015.

3) Tidak ada hubungan antara sikap dengan perilaku perilaku K3 di PT Arteria Daya Mulia (ARIDA) Cirebon tahun 2015.

4) Ada hubungan antara motivasi dengan perilaku K3 di PT Arteria Daya Mulia (ARIDA) Cirebon tahun 2015.

5) Ada hubungan antara komunikasi dengan perilaku K3 di PT Arteria Daya Mulia (ARIDA) Cirebon tahun 2015.

3. Ada hubungan antara faktor Enabling (ketersediaan fasilitas APD ) dengan perilaku K3 di PT Arteria Daya Mulia (ARIDA) Cirebon tahun 2015. 
4. Hubungan antara faktor reinforcing (pengawasan, hukuman dan penghargaan) dengan perilaku K3 .

1) Ada hubungan antara pengawasan dengan perilaku K3 di PT Arteria Daya Mulia (ARIDA) Cirebon tahun 2015.

2) Tidak ada hubungan antara hukuman dengan perilaku K3 di PT Arteria Daya Mulia (ARIDA) Cirebon tahun 2015.

3) Tidak ada hubungan antara penghargaan dengan perilaku K3 di PT Arteria Daya Mulia (ARIDA) Cirebon tahun 2015.

\section{SARAN}

\section{Bagi Perusahaan}

1) Perusahaan mengadakan STOP (safety training observation program) yang dapat melatih pekerja untuk mengamati, membetulkan, mencegah dan melaporkan tindakan penyimpangan secara sistematis. Selain itu juga melatih untuk mengamati dan menanamkan praktek kerja selamat.

2) Perlu diadakan penghargaan (reward) dan hukuman (punishment) sebagai motivasi bagi pekerja agar dapat berperilaku K3.

3) Mempersiapkan APD yang lengkap yang sesuai dengan standar dan sesuai dengan potensi bahaya di tempat kerja.

\section{Bagi Pekerja}

1) Pekerja menggunakan dan menjaga perlengkapan keselamatan kerja dengan lengkap dan benar, mentaati peraturan dan prosedur yang berlaku, bekerja sesuai dengan tanggung jawabnya.

2) Pekerja bekerja sesuai dengan Standard Operational Procedur (SOP).

\section{Bagi Peneliti lain}

Peneliti selanjutnya diharapkan mengikutsertakan variabel - variabel lain yang diduga berhubungan dengan perilaku K3 yang tidak dapat diteliti pada peneitian ini.

\section{DAFTAR PUSTAKA}

1. Dauzz Simohol. Kumpulan makalah FKM; [di akses tanggal 30 Mei 2015]. Di unduh dari (http://dauzzsimoholkumpulanmakalahfkm.blogspot.com)

2. Suma'mur. Keselamatan kerja dan pencegahan kecelakaan. Jakarta: PT.Gunung Agung; 2005

3. Notoatmodjo Soekidjo. Promosi kesehatan dan ilmu perilaku. Jakarta: RinekaCipta; 2007

4. Anonym. Kecelakaan kerja di Jabar capai 22.438 kasus: [di akses tanggal 11 Mei 2015]. Di unduh dari: http://m.republika.co.id

5. Makhrudin Ade. Gambaran perilaku pekerja terhadap program keselamatan dan kesehatan Kerja. Depok: Skripsi UI; 2007

6. Anonim. Profil Arteria Daya Mulia (ARIDA) Cirebon: PT ARIDA; 2015

7. Anonim. Data kecelakaan kerja Di PT Arteria Daya Mulia (ARIDA) Cirebon: PT ARIDA; 2015

8. Riyanto, Agus. Aplikasi metodologi penelitian kesehatan.Yogyakarta: Nuha medika; 2011

9. Sugiyono, Metode penelitian kuantitatif, kualitatif dan R\&D. Bandung: Alfabeta; 2012

10. Sahab, Syukri. Teknik manajemen keselamatan dan kesehatan kerja. Jakarta: PT. Bina Sumber Daya Manusia; 1997

11. Widayatun Rusmi Tri. Ilmu perilaku M.A. 104 "Buku Pegangan Mahasiswa AKPER".Jakarta: CV. Sagung Seto; 1999 
12. Syaaf, Fathul Mashuri. Analisis perilaku beresiko (at-risk behavior) pada pekerja unit usaha las sector informal di Kota X. Depok: Skripsi Program Sarjana Kesehatan Masyarakat Universitas Indonesia; 2008

13. Notoatmodjo Soekidjo. Pendidikan dan perilaku kesehatan. Jakarta: Rineka Cipta; 2003

14. Munandar, Sunyoto Ashar. Psikologi industri dan organisasi. Jakarta: UI Press; 2001

15. Sialagan, Togar Robin. Analisis faktor - faktor yang berkontribusi pada perilaku aman di PT EGS Indonesia. Depok: Tesis FKM UI; 2008

16. Asriyani. Faktor - faktor yang mempengaruhi sikap penggunaan alat pelindung diri pada pekerja bagian Sistem Telepon Otomatis (STO) PT. Telekomunikasi, Tbk. Riau-Daratan Kota Pekanbaru. Jakarta: Skripsi Program Studi Kesehatan Masyarakat Universitas Pembangunan Nasional (Veteran) Jakarta;2011 